\title{
Comparative Analysis of Salary, Labor Intensity and Payroll-Output Ratio of Foreign and Domestic Firms: Case Russian Vehicle Industry
}

\author{
Vladislav Spitsin* \\ Department of Management \\ Tomsk Polytechnic University \\ Tomsk, Russia \\ Spitsin_vv@mail.ru \\ *Corresponding author \\ Lubov Spitsina \\ Department of Economics \\ Tomsk Polytechnic University \\ Tomsk, Russia \\ s_luba_07@mail.ru \\ Tyuleneva Nataliya \\ Department of Finance and Accounting \\ Tomsk State University \\ Tomsk, Russia \\ aola79@yandex.ru
}

\author{
Aleksandr Mikhalchuk \\ Department of Higher Mathematics \\ Tomsk Polytechnic University \\ Tomsk, Russia \\ aamih54@gmail.com
}

\author{
Elena Akerman \\ Department of state management \\ Tomsk State University \\ Tomsk, Russia \\ aker@tomsk.gov.ru \\ Aleksei Semes \\ Tomsk Polytechnic University \\ Tomsk, Russia \\ Darya Novoseltseva \\ Tomsk Polytechnic University \\ Tomsk, Russia
}

\begin{abstract}
The article presents the results of statistical analysis of differences in average salaries, labor intensity and payroll-output ratio for businesses with different ownership. The analysis included companies in vehicle production industry in various regions of Russia. We found that foreign and joint enterprises have on the average higher salaries with lower labor intensity and payroll-output ratio than the same indicators for domestic (Russian) enterprises. These results are supported by considerable significance of both parametric and non-parametric criteria for tested statistical hypothesis correspondence to averages values. Lower labor intensity and lower payroll-output ratio (or higher productivity) provide certain economic benefits (effects) for foreign and joint enterprises. However, it can lead to negative social results of the studied industry, since it will cause reduction in employment and payrolls.
\end{abstract}

Keywords-foreign and joint enterprises; domestic enterprises; wages; salary; labor intensity; productivity; payroll-output ratio; statistical analysis; vehicle industry; Russia

\section{INTRODUCTION}

Since 2006, foreign and joint enterprises (foreign and joint ownership - FJO) have been intensively created in several industries of the Russian economy. These processes run especially intensively in the DM subsection "Production of Vehicles and Equipment" (C29+C30 according to the NACE Rev. 2, Eurostat classification of economic activities). The production volumes of the foreign and joint enterprises in this subsection reached $42 \%$ in 2013 and became comparable to the enterprises in the domestic property (Russian ownership - RO).

The aim of this research is to test the hypothesis of higher average salary, lower labor intensity and lower payroll-output ratio on foreign and joint enterprises in comparison with domestic ones. The aim will be achieved by investigating these indicators at the regional level for the Russian vehicle industry by the types of ownership. The research period is 2010-2013. The information base includes statistical data at the level of Russia and its regions.

In the world economic science, the various aspects of influence of the country's business owners on a condition of national labor market have been studied in detail [1-6]. The majority of studies are carried out by the analysis of statistical information at the level of the company, region or country in the context of the main branches of goods production and services. The studies produced the following results:

- The foreign companies hire the most qualified employees; practically everywhere the salary is higher than in national companies.

- The high-tech competitors negatively influence the labor productivity of national companies and 
employment rate in the country, but positively influence the level of goods quality and commodity saturation of the national market.

- The role of foreign companies in national specialists' growth of skills is important. This technologic exchange is one of innovative development factors and must be supported by the state.

- The interrelations of companies' functioning in foreign and joint property and national labor market can be easily described by means of statistical and mathematical models, which vary depending on the purposes of each study.

We studied the labor market characteristics and problems of employment in Russia in [7]. The aim of this research is to investigate whether the average salary, labor intensity and payroll-output ratio differ between foreign and joint enterprises and domestic ones for the case of Russian vehicle industry.

\section{RESEARCH METHODOLOGY}

The 5 indicators (Table 1) were used for the analysis. The values of these indicators on the DM subsection at the level of Russia are given in Table 2.

The data, presented in Table 2, allow to assume distinctions on each indicator between foreign and joint firms and domestic enterprises. The standard procedure of the statistical analysis is applied to test this hypothesis. Statistical analysis is carried out at the level of Russian regions. We formed two samples of regions for vehicle industry:

- The sample of regions in which foreign and joint enterprises produced significant volumes of products.

- The sample of regions in which domestic (Russian) enterprises produced significant volumes of products.

TABLE I. IINDICATORS AND THEIR CALCULATIONS

\begin{tabular}{|l|l|l|}
\hline № & \multicolumn{1}{|c|}{ Name } & \multicolumn{1}{c|}{ Calculation formula } \\
\hline 1 & Average salary & Average monthly salary, rub. \\
\hline 2 & $\begin{array}{l}\text { Ratio of average } \\
\text { salaries in DM }\end{array}$ & $\begin{array}{l}\text { Average salary of the studied form of } \\
\text { ownership DM / the Average salary in } \\
\mathrm{DM} * 100, \%\end{array}$ \\
\hline 3 & $\begin{array}{l}\text { Ratio of average } \\
\text { salaries in DM } \\
\text { and } \mathrm{D}^{\mathrm{a}}\end{array}$ & $\begin{array}{l}\text { Average salary of the studied form of } \\
\text { ownership DM / the Average salary in } \\
\mathrm{D} * 100, \%\end{array}$ \\
\hline 4 & $\begin{array}{l}\text { Labor intensity } \\
\text { (inverse labor } \\
\text { productivity) }\end{array}$ & $\begin{array}{l}\text { Number of persons employed / Production } \\
\text { value, person / 10 mln. rubles. }\end{array}$ \\
\hline 5 & $\begin{array}{l}\text { Payroll-output } \\
\text { ratio }\end{array}$ & Payroll fund / Production value * 100,\% \\
\hline
\end{tabular}

a. D - manufacturing industry. It corresponds to the section C according to the Eurostat classification of economic activities

TABLE II. VALUES OF INDICATORS FOR THE RUSSIAN VEHICLE INDUSTRYA

\begin{tabular}{|l|l|l|l|l|l|}
\hline \multirow{2}{*}{ Form of ownership } & \multicolumn{5}{|c|}{ Indicators } \\
\cline { 2 - 6 } & $\mathbf{1}$ & $\mathbf{2}$ & $\mathbf{3}$ & $\mathbf{4}$ & $\mathbf{5}$ \\
\hline FJO & 28000 & 108 & 121 & 1,8 & 6,1 \\
\hline RO & 25440 & 98 & 110 & 5,8 & 17,6 \\
\hline
\end{tabular}

We tested the hypothesis of similarity or differences of means values for each indicator between these samples of regions. We excluded from the samples the next regions:

- The regions, in which average annual production of subsection DM by the analyzed ownership form was less than 1 billion rubles.

- The regions, in which there were insufficient data for analysis or very anomalous values of relative indicators

- The following samples of regions with different ownership forms of enterprises were received:

- Russian enterprises (RO) - 59 regions;

- Foreign and joint enterprises (FJO) - 21 regions.

Each sample of regions covered more than $90 \%$ of the total employment and payroll fund of subsection DM by the same ownership form. To reduce the variability of the indicators in the statistical analysis, we calculated and used their average values for the period 2010-2013.

\section{RESUlTS OF STATISTICAL ANALYSIS}

\section{A. Tests whether data is normally distributed}

To correct application of testing criteria for the means, it is necessary first to assess the similarity of the observed distributions (histograms) of indicators by the ownership forms with the theoretical distribution by the normal distribution. According to $\chi 2$-Pearson only sample RO-2 (distribution of indicator №2 for the Russian ownership) is insignificantly (at a level of significance $p>0,10$ ) different from the normal distribution. The remaining samples demonstrate different levels of significance differences from the theoretical normal distribution. For example, the indicator №1 (Fig. 1) for distribution of the RO (RO-1) differs from the normal distribution statistically significantly $(0,050>p \approx 0,018>$ $0,005)$, and FJO-1 - highly significantly $(0,0005>\mathrm{p})$.

Due to the small size of the FJO sample and violation of the normal distribution of samples we used both the parametric $t$ test and non-parametric U - test Mann-Whitney in the research. In case of disputes, the results of nonparametric criterion were considered to be priority.

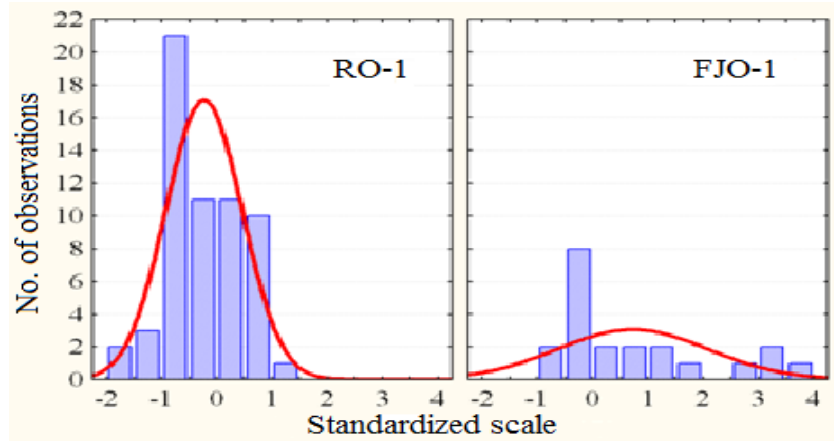

FIGURE I. COMPONENTS OF THE HISTOGRAM OF INDICATOR №1 (RO-1 AND FJO-1) WITH THE CORRESPONDING CURVES FOR THE NORMAL DISTRIBUTION 


\section{B. The test hypotheses for sample means}

The null hypothesis was tested by parametric and nonparametric criterion. Parametric criterion (t-test) is testing, that independent population means are equal. Nonparametric criterion (U- test Mann-Whitney) is test whether the medians of two independent populations differ. This results presented in table 3 .

Based on data in Table 3, the differences of the following indicators in the context of ownership forms were confirmed with high confidence. The differences are highly significant for the indicators №4 and №5 $(0,0005>$ p) and they are strongly significant for the indicators №1, №2 and №3 $(0,005 \geq \mathrm{p}>$ $0,0005)$. Nonparametric $U$ - test only slightly softens the significance levels of means differences and it don't change the results of parametric t-criterion. Fig. 2 illustrates a component (by indicators) geometric interpretation of the samples examined.

Strongly significant heterogeneity of the samples of each indicator graphically illustrated in Fig. 2 by comparison the parameters characteristic of foreign and joint enterprises and Russian ones. The same strongly significant heterogeneity is confirmed by comparison of their histograms in Figure 1 for the indicator №1 (PO-1 and FJO-1).

Mean values of indicators for the compared samples (RO and FJO) and their differences (|FJO - RO |/ RO) are presented in Table 4.

According the table 4 labor intensity (№4) and payrolloutput ratio (№5) of foreign and joint enterprises is significantly lower (nearly twice) than the Russian (domestic) ones. The average salary of foreign and joint enterprises (№1) (and the corresponding relative indicators №2 and №3) is higher than the Russian (domestic) ones. We think that the indicators №2 and №3 estimate more correctly the differences in salary because they exclude the effect of various sample sizes. According them the average salary of foreign and joint enterprises is approximately $15-20 \%$ higher than Russian ones. But the higher average salary does not compensate the lower labor intensity.

FIGURE II. THE SIGNIFICANCE LEVELS OF TWO-SAMPLE TESTS OF MEANS FOR EACH INDICATOR

\begin{tabular}{|c|c|c|c|c|c|c|c|c|c|}
\hline Indicators & \multicolumn{2}{|c|}{ №1 } & \multicolumn{2}{|c|}{ №2 } & \multicolumn{2}{|c|}{ №3 } & \multicolumn{2}{|c|}{ №4 } & №5 \\
\hline \multicolumn{10}{|c|}{ Parametric $t$ - test } \\
\hline $\mathrm{RO}$ and $\mathrm{FJO}$ & \multicolumn{2}{|c|}{0,0001} & \multicolumn{2}{|c|}{0,00000} & \multicolumn{2}{|c|}{0,0021} & \multicolumn{2}{|c|}{0,00000} & 0,00007 \\
\hline \multicolumn{10}{|c|}{ Nonparametric $U$ - test Mann-Whitney } \\
\hline $\mathrm{RO}$ and $\mathrm{FJO}$ & \multicolumn{2}{|c|}{0,0031} & \multicolumn{2}{|c|}{0,0019} & \multicolumn{2}{|c|}{0,0054} & \multicolumn{2}{|c|}{0,00000} & 0,00002 \\
\hline \multicolumn{10}{|c|}{$\begin{array}{l}\text { FIGURE III. } \\
\text { MEAN VALUES AND DIFFERENCES OF } \\
\text { INDICATORS FOR THE SAMPLES OF REGIONS }\end{array}$} \\
\hline \multirow{2}{*}{\multicolumn{2}{|c|}{$\begin{array}{c}\text { Type of } \\
\text { ownership forms }\end{array}$}} & \multicolumn{8}{|c|}{ Indicators } \\
\hline & & & & & & & & №4 & №5 \\
\hline \multicolumn{2}{|c|}{ RO } & \multicolumn{2}{|c|}{23102,33} & \multicolumn{2}{|c|}{98,46} & \multicolumn{2}{|c|}{110,68} & 7,33 & 19,44 \\
\hline \multicolumn{2}{|l|}{$\mathrm{FJO}(\mathrm{FO}+\mathrm{JO})$} & \multicolumn{2}{|c|}{32369,35} & \multicolumn{2}{|c|}{113,66} & \multicolumn{2}{|c|}{129,32} & 3,09 & 9,62 \\
\hline \multicolumn{2}{|l|}{ deviation, \% } & \multicolumn{2}{|c|}{40,11} & \multicolumn{2}{|c|}{15,44} & \multicolumn{2}{|c|}{16,84} & 57,84 & 50,51 \\
\hline
\end{tabular}

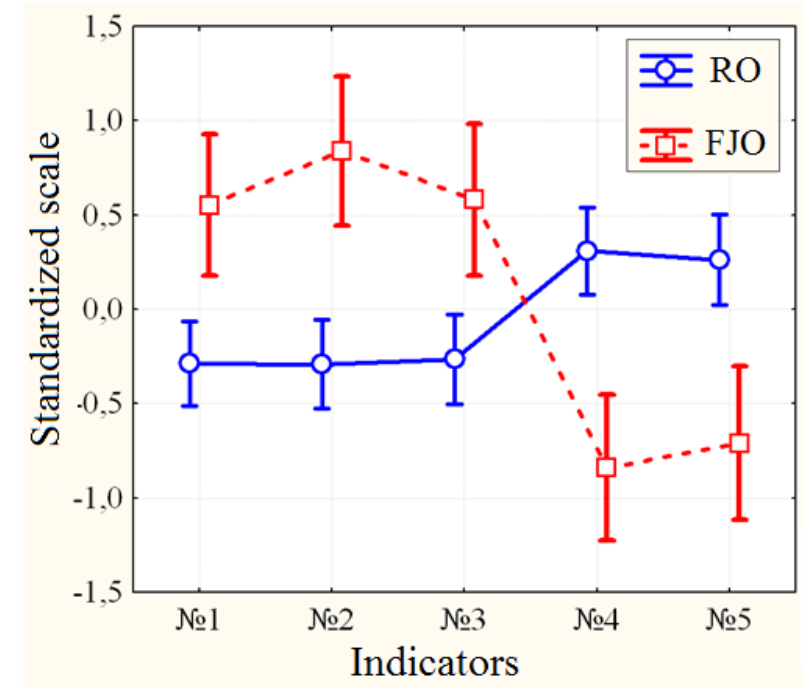

FIGURE IV. $\quad$ LINEAR PLOTS OF MEAN FJO, RO WITH 95\% CONFIDENCE INTERVALS IN THE SYSTEM OF THE STANDARDIZED INDICATORS

\section{CONCLUSIONS}

We determined the differences of labor intensity, payrolloutput ratio, and average salary between the foreign and joint enterprises and the Russian (domestic) enterprises. Labor intensity and payroll-output ratio of foreign and joint enterprises is significantly lower (nearly twice) than the Russian (domestic) ones. The average salary is higher, but it does not compensate the lower labor intensity. The differences is in agreement with the fact that the most foreign and joint enterprises in Russian vehicle industry is assembly plants. How do these differences affect the enterprises and the Russian economy?

It is the obvious economic effect of lower labor intensity and lower payroll-output ratio (and consequently higher productivity) for the newly created foreign and joint companies and theirs founders.

However, at the level of Russian economy situation does not look so one-valued. Positive effects:

- The production of higher quality goods on modern foreign technologies.

- Creation of new jobs and production centers.

- Adverse effects:

- Foreign and joint enterprises are not oriented to the external market and compete with Russian firms for the redistribution of a fixed volume of the internal market.

- Low social effects (low employment) leads to the fact that the jobs created by foreign and joint firms do not compensate for job losses at Russian enterprises.

It is planned to continue the study of distinctions between foreign, joint and domestic enterprises in Russian vehicle industry. We are going to analyze the differences of their investment activity and growth rates. 


\section{ACKNOWLEDGMENT}

The research is made with financial support from Russian Foundation for Basic Research (RFBR) in the frames of scientific and research project of RFBR named "Comprehensive economic and statistical impact analysis of joint and foreign ownership enterprises on the industry development in Russia and its regions”, project №15-06-05418.

\section{REFERENCES}

[1] Z. Chen, Y. Ge, and H. Lai, "Foreign Direct Investment and Wage Inequality: Evidence from China," World Development, 39, № 8, pp. $1322-1332,2011$.

[2] W. Chen, "The effect of investor origin on firm performance: Domestic and foreign direct investment in the United States," J. of International Economics, 83, is. 2, pp. 219-228, March 2011.

[3] S. Girma, Y. Gong, and H. Goërg, "What Determines Innovation Activity in Chinese State-owned Enterprises? The Role of Foreign Direct Investment,” World Development, 37, № 4, pp. 866-873, 2009.

[4] Y. Temouri, N. Driffield, and D. Higón, "Analysis of Productivity Differences among Foreign and Domestic firms: Evidence from Germany," The Review of World Economics, 144(1), pp. 32-54, 2008.

[5] Y. Murakami, "Technology spillover from foreign-owned firms in Japanese manufacturing industry," J. of Asian Economics, 18, pp. 284$293,2007$.

[6] R. B. Papalia, and P. Calia, "A novel factor decomposition of productivity differentials: evidence from foreign owned and domestic firms in Italy," WSEAS Transactions on Business and Economics., is. 4, vol. 7, pp. 332-348, October 2010

[7] N. O. Chistyakova, M. K. Semenova , V. V. Spitsyn, and P. Paquet, "Problems of Educational Processes Development and Labor Market Needs Analysis in Russia," Procedia - Social and Behavioral Sciences, vol. 166, pp. 309-316, 2015. 